\title{
POLÍTICA DA ARTE!1
}

\author{
Tradução de Mônica Costa Netto
}

Resumo

Reflexão sobre as noções de arte pública, a fotografia como obra de arte e a extensão dos museus para seu exterior, através de instalações. Questões sobre os fundamentos da estética, da comunidade social e da arte crítica são enfocadas, como intuito de se pensar a condição atual de politização da arte dentro do contex to globalizado.

Palavras-chave: arte, sociologia da arte, política da arte.

\begin{abstract}
Reflexions on the concepts of public art, photography as art and the extension of museum's installations. Questions about aesthetics foundations, social community and combatent art are focused, aiming at considering the current condition of the politicization of art within the global context.
\end{abstract}

Keywords: art, art sociology, art politics.

Introduzirei meu tema com três exemplos, três manifestações contemporâneas da política da arte que me parecem significativas.

A primeira é extraída do universo da arte pública, a arte que se inscreve na paisagem da cidade e da vida em comum, distinta da que é vista nos museus. Há alguns anos vem se desenvolvendo uma nova forma de arte pública: uma arte que intervém em lugares mais ou menos marcados pelo abandono social e pela violência, e que age modificando a paisagem da vida coletiva no sentido de restaurar uma forma de vida social. Assim, há dois anos, na França, uma fundação belga recompensou um projeto apresentado pelo grupo de artistas franceses "Acampamento urbano". O projeto se denominava "Eu e nós" e consistia em edificar, num bairro particularmente difícil do subúrbio parisiense, uma nova forma de espaço público. Eu cito: "um lugar inútil, extremamente frágil e não produtivo”. Este lugar deveria ser acessível a todos e ficar sob a

${ }^{1}$ Conferência

realizada por Jacques Rancière em abril de 2005, no seminário Práticas estéticas, sociais e políticas em debate.

São Paulo: Sesc Belenzinho.

Disponível em: $<$ www.sescsp.org.br/ sesc/conferencias>

${ }^{2}$ Tradutora de Rancière no Brasil, responsável pelas traduções de $A$ partilha do sensível e 0 inconsciente estético. 
guarda de todos. Mas ele só podia ser ocupado por uma pessoa a cada vez e devia permitir, assim, "o recolhimento de um Eu possível no Nós”.

Meu segundo exemplo nos remete ao espaço do museu e da exposição. Trata-se do privilégio concedido em várias exposições contemporâneas à chamada fotografia objetiva. Uma obra fotográfica parece emblematizar de modo particular essa tendência: trata-se das torres de reservatório d'água, dos altosfornos e outras construções industriais fotografados segundo um protocolo imutável por Bernd e Hilla Becher.

Meu terceiro exemplo será encarregado da transição entre o museu e o seu exterior. Na última Bienal de São Paulo podia-se assistir a uma instalação de vídeo realizada pelo artista cubano Rene Francisco. Este artista havia utilizado a verba concedida por uma fundação artística numa pesquisa nos bairros pobres de Havana. Em seguida, ele selecionou um casal de velhos e decidiu, com a ajuda de amigos artistas, refazer as instalações da casa deles. A obra nos mostrava uma tela de tule na qual a imagem impressa do casal de velhos olhava para a tela do monitor em que nós podíamos ver os artistas trabalhando como pedreiros, pintores ou bombeiros.

Percebe-se o que une esses exemplos. Todos três dizem respeito a questões de lugar, construção e habitação. Todos três definem uma determinada relação entre o dentro e o fora, que também é uma determinada relação entre arte, trabalho e distribuição do espaço social. Todos três nos lembram que a arte não é política antes de tudo pelas mensagens que ela transmite nem pela maneira como representa as estruturas sociais, os conflitos políticos ou as identidades sociais, étnicas ou sexuais. Ela é política antes de mais nada pela maneira como configura um sensorium espaço-temporal que determina maneiras do estar junto ou separado, fora ou dentro, face a ou no meio de... Ela é política enquanto recorta um determinado espaço ou um determinado tempo, enquanto os objetos com os quais ela povoa este espaço ou o ritmo que ela confere a esse tempo determinam uma forma de experiência específica, em conformidade ou em ruptura com outras: uma forma específica de visibilidade, uma modificação das relações entre formas sensíveis e regimes de significação, velocidades específicas, mas também e antes de mais nada formas de reunião ou de solidão. Porque a política, bem antes de ser o exercício de um poder ou uma luta pelo poder, é o recorte de um espaço específico de "ocupações comuns"; é o conflito para determinar os objetos que fazem ou não parte dessas ocupações, os sujeitos que participam ou não delas, etc. Se a arte é política, ela o é enquanto os espaços e os tempos que ela recorta e as formas de ocupação desses tempos e espaços que ela determina interferem com o recorte dos espaços e dos tempos, dos sujeitos e dos objetos, do privado e do público, das competências e das incompetências, que define uma comunidade política. 
Retornemos desse ponto de vista a meu primeiro exemplo. O projeto recompensado pela fundação artística não remete a nenhuma arte em particular. Ele apresenta a pura ideia da arte como recorte de um lugar comum, poder-se-ia dizer, no sentido forte do termo, um senso comum. "Eu e Nós" soa como uma abreviação da universalidade subjetiva kantiana do juízo de gosto. E o lugar apartado que ele define, bem poderia ser a última forma de um tipo de espacialização da arte surgido mais ou menos na mesma época que o conceito de estética, que é também a época da Revolução Francesa. Isto é, o museu, um lugar onde visitantes solitários e passivos vêm encontrar a solidão e a passividade de obras despojadas de suas antigas funções de ícones da fé, de emblemas do poder ou de decoração da vida dos Grandes.

É o que significa a palavra "estética”. A estética não designa a ciência ou a filosofia da arte em geral. Esta palavra designa antes de tudo um novo regime de identificação da arte que se construiu na virada do século XVIII e XIX: um determinado regime de liberdade e de igualdade das obras de arte, em que estas são qualificadas como tais não mais segundo as regras de sua produção ou a hierarquia de sua destinação, mas como habitantes iguais de um novo tipo de sensorium comum onde os mistérios da fé, os grandes feitos dos príncipes e heróis, um albergue de aldeia holandesa, um pequeno mendigo espanhol ou uma tenda francesa de frutas ou de peixes são propostas de maneira indiferente ao olhar do passante qualquer, o que não quer dizer à totalidade da população, todas as classes confundidas, mas a esse sujeito sem identidade particular chamado "qualquer um”. O lugar solitário proposto à meditação de um eu qualquer no nós dos subúrbios deserdados é claramente um herdeiro desse espaço paradigmático da estética. É um museu esvaziado de toda obra e conduzido à igualdade indiferente que é seu princípio.

Mas existem duas maneiras de tratar essa igualdade. A primeira é resumida na obra de Pierre Bourdieu chamada A Distinção. Essa maneira consiste em desmistificar a indistinção - ou a "igualdade" - estética, fazendo dela um simples biombo destinado a dissimular a realidade da distinção, a realidade da incorporação social dos juízos de gosto e do mercado de bens simbólicos. Este tipo de desmistificação certamente assegura uma aliança a baixo custo entre progressismo científico e progressismo político. Mas, somente ao preço de fazer esvaecer seu objeto. A crítica político-científico da ilusão estética faz desaparecer algo crucial: existe uma política da estética - que não é uma ilusão de filósofos cândidos - mas uma realidade bi-secular, encarnada nas instituições da arte, nas formas materiais da sua visibilidade, nos olhares e julgamentos que nos permitem discerni-la e até mesmo nas teorias científicas e políticas que pretendem nos dizer a verdade sobre a ilusão estética. É portanto mais interessante deixar de lado o conforto barato dos desmistificadores para estudar diretamente essa forma singular de liberdade e igualdade que a estética 
vinculou à própria identificação da arte. Portanto, no lugar de denunciar a ilusão estética, vale a pena examinar o paradoxo que estrutura o regime estético da arte e sua política. Este paradoxo é a constituição de um senso comum paradoxal, um "senso comum" que é político na medida em que ele é sede de uma indiferença radical.

Essa política da indiferença poderia ser resumida na encenação discursiva de uma estátua decaptada, apresentada na Alemanha trinta anos antes da decapitação revolucionária do rei da França. Estou falando da descrição feita por Winckelmann do Torso do Belvedere, a estátua de um herói, despojada de tudo que caracterizava o regime representativo da expressão artística: sem rosto para expressar um sentimento, sem boca para manifestar uma mensagem, sem membros para comandar ou executar ação alguma. Winckelmann decidiu que se tratava de uma estátua de Hércules. Mas de um Hércules bastante particular: por um lado, toda a identidade espiritual do herói dos Doze Trabalhos devia estar concentrada na parte do corpo que já não expressa sentimento nenhum, unicamente no desenho dos músculos, sem com isso indicar ainda uma ação interpretável. Por outro lado, este Hércules era um Hércules de depois dos Trabalhos, um Hércules ocioso, acolhido entre os deuses ao término de suas provas. De modo que aquilo que devia ser lido nos músculos do Torso, era o movimento ultrapassado, o movimento igualado ao repouso, o "trabalho" igualado à ociosidade. O que ele expressava era uma beleza específica, a beleza de uma união imediata dos contrários, de uma expressão integral da vida igual à ausência de expressão.

Dessa indiferença radical que definia uma nova ideia do belo, Winckelmann fez a manifestação de uma beleza antiga perdida, a da arte grega clássica. Dessa beleza perdida, ele fez a expressão de uma liberdade perdida, a do povo grego. Dessa liberdade, ele fez a identidade feliz de um agir e de um ser-aí, a manifestação de um povo totalmente ativo em razão de sua total adequação à terra que o alimentava e ao céu que ele contemplava.

É preciso tomar a medida exata do que está em jogo nesse torso de trabalhador separado de seus membros de trabalhador, que também é um deus separado dos instrumentos da sua vontade: a ruptura de um esquema da adequação entre a distribuição das condições ou ocupações e a distribuição de corpos e equipamentos corporais adaptados a essas condições e ocupações. É o que Schiller comentará trinta anos depois de Winckelmann e dois anos depois da decapitação do rei da França, a propósito, desta vez, de uma cabeça sem corpo, a da Juno Ludovisi: a cabeça de uma deusa que não comanda nem obedece a ninguém, que não faz nem quer nada. O que essa cabeça ociosa, indiferente, simboliza é a neutralização da oposição entre a atividade e a passividade, isto é, da partilha do mundo entre a classe dos homens ativos, que 
são os homens "do lazer" e a dos homens passivos, a dos homens destinados à passividade do trabalho reprodutor. Schiller viu nisto o princípio de uma revolução da experiência sensível, sem a qual a revolução das formas do Estado se perde no terror. Mas, uma vez mais, não se trata aí de um simples assunto de filósofos cândidos ou poetas delicados. O que Schiller assinala a seu modo é essa nova forma de existência das obras de arte, que se dá num modo de visibilidade que confunde materialmente a distribuição dos lugares e das funções, e uma forma de experiência que confunde a relação funcional das identidades sociais e dos "equipamentos corporais". Assim, no decorrer da Revolução de 1884 na França, o fantasma do herói sem braços nem pernas e do movimento recolhido em imobilidade assombra uma narrativa publicada num jornal revolucionário operário: a narrativa da emancipação "estética” pela qual um operário da construção se forja um novo corpo, separando seu olhar contemplador dos braços que trabalham para o patrão: eu cito: "Sentindo-se em casa enquanto ainda não terminou o piso do cômodo em que trabalha, ele desfruta da tarefa; se a janela se abre para um jardim ou domina um horizonte pitoresco, por um instante ele repousa seus braços e plana em ideias para a espaçosa perspectiva, gozando dela melhor do que os proprietários das casas vizinhas". A constituição de uma "voz" política - de um “nós” - dos trabalhadores passa por essa reconfiguração da experiência sensível de um "eu”, por essa dissociação da capacidade dos braços e da capacidade do olhar, que desfaz a aderência de um "equipamento corporal” a uma condição.

Se não podemos deixar de ver o museu por detrás do lugar apartado do "Acampamento urbano", os altos-fornos abandonados dos Becher e o vídeo dos artistas transformados em trabalhadores da construção nos remetem a essa relação entre o torso mutilado do herói que terminou seus trabalhos e a disjunção operada entre os braços e o olhar do operário da construção. As fotografias dos altos-fornos se inscrevem num espaço de "solidão" que se tinha constituído em torno da estátua do trabalhador ocioso. A reportagem do trabalho dos artistas cubanos recoloca em cena o grande projeto surgido em torno da relação imaginada da estátua com o seu povo: o projeto de uma arte que, como o dirá Malevitch, após a Revolução de 17, não fabrica mais obras de arte mas formas de vida, e consacra seus museus não mais às velhas estátuas gregas mas aos projetos de construção do futuro. Dir-se-á que se tratam de exemplos mínimos ou até mesmo caricaturais. Mas a "caricatura" também é uma projeção que nos permite compreender o que a "política da arte" pode significar e qual tensão fundamental habita a história dessa política.

A própria oposição entre a fábrica abandonada e o vídeo dos artistas de boa vontade nos lembra que: os grandes projetos do porvir comunista podiam substituir as velhas estátuas gregas nos museus por uma razão muito simples: porque o futuro dos projetos comunistas e o passado das velhas 
estátuas gregas têm a ver com um mesmo núcleo fundamental: o da política da estética. Do mesmo modo, as oposições convencionais entre a autonomia e a heteronomia da arte, arte pela arte e arte engajada remetem a um único e mesmo paradigma fundamental: o dessa estátua que promete um futuro de emancipação coletiva em razão de sua posição solitária, indiferente, assim como a construção de um novo mundo em razão mesmo de sua ausência de toda vontade que comande e de todo membro que execute. A política da arte no regime estético das artes repousa sobre o paradoxo originário dessa "liberdade de indiferença" que significa a identidade de um trabalho e de uma ociosidade, de um movimento e de uma imobilidade, de uma atividade e de uma passividade, de uma solidão e de uma comunidade. Não existe uma pureza estética oposta a uma impureza política. É a mesma “arte” que se expõe na solidão dos museus à contemplação estética solitária e que se propõe trabalhar na construção de um novo mundo.

Mas a política da indiferença também dá lugar a duas políticas estéticas alternativas. A promessa de comunidade embutida na estátua grega mutilada se deixa interpretar desde o início de duas maneiras. A estátua promete um futuro de liberdade e igualdade por duas razões opostas. Ela o promete, uma primeira vez, porque ela é arte, porque ela é algo "extremamente inútil, frágil e não produtivo”, pertencendo a um tempo-espaço próprio, o do museu, e que define uma experiência sensível desconectada das condições normais da experiência sensível e das hierarquias que a estruturam. Ela o promete, uma segunda vez, pela razão inversa: porque ela não foi produzida como obra de arte destinada a um museu, mas como manifestação de uma vida coletiva para a qual a arte não existia como categoria separada, em que a arte não se separa da vida pública nem a vida pública da coletividade da vida concreta de cada um.

A partir daí definiram-se dois grandes paradigmas da política da estética. O primeiro privilegia o movimento recolhido na imobilidade da estátua, a atividade expressa na sua passividade, a comunidade manifestada na sua solidão. O que a liberdade de indiferença da estátua expressa, assim, é uma indiferenciação da arte e da vida. E o futuro que sua solidão promete é um futuro em que essa solidão será suprimida, onde a liberdade e a igualdade excepcionais da experiência estética serão incorporadas nas formas da experiência comum. A experiência estética deve realizar sua promessa suprimindo sua particularidade, construindo as formas de uma vida comum indiferenciada, onde arte e política, trabalho e lazer, vida pública e existência privada se confundam. Ela define portanto uma metapolítica, isto é, o projeto de realizar realmente aquilo que a política realiza apenas aparentemente: transformar as formas da vida concreta, enquanto a política se limita a mudar as leis e as formas estatais. 
Trata-se do programa cuja primeira expressão se deu na época da Revolução Francesa, no Primeiro programa sistemático do idealismo alemão, que visava substituir o mecanismo morto do Estado pelo corpo vivo de um povo animado por uma filosofia transformada, pelos poetas, em mitologia. Foi esse projeto que animou tanto o retorno ao artesanato sonhado pelo Arts and Crafts quanto os grandes manifestos modernistas do Werkbund ou do Bauhaus e a participação de artistas futuristas, suprematistas e construtivistas na revolução soviética. Essa solidariedade da revolução artística e da revolução marxista atesta uma solidariedade mais fundamental. Pois o projeto marxista de uma revolução radical, capaz de mudar as formas de produção e de circulação que são a realidade profunda da vida coletiva, escondidas sob as formas e aparências da política, é ele próprio dependente da metapolítica estética. O que quer dizer que a "revolução estética" define algo completamente distinto de um modo de percepção das obras de arte. Neste paradigma, a arte está destinada a se realizar se suprimindo para fundir-se com uma política que, também ela, se realiza se suprimindo.

A este paradigma se opôs a interpretação inversa da "estética”. Nessa interpretação, o poder revolucionário de indiferença repousa inteiramente na solidão da estátua ociosa e na separação estrita da experiência estética de toda funcionalidade. É o que resume o paradoxo de Adorno: "A função social da arte é a de não ter função." O potencial de emancipação da obra se encontra inteiramente na sua ociosidade, isto é, no seu distanciamento com relação a todo "trabalho" social, a toda participação em uma obra de transformação militante ou em toda tarefa de embelezamento do mundo comercial e da vida alienada. Ao programa da arte que deve se realizar se suprimindo responde essa política que deve se abster de toda política. Tal política, contudo, não pode ser reduzida à simples ideia da autonomia da arte. $\mathrm{O}$ que essa separação da arte sustenta de fato, em Adorno, não é a pureza da arte, mas sua impureza, a marca da divisão do trabalho que a institui como realidade separada. De modo que a perfeição da estátua mutilada revela, não a plenitude da vida de um povo, mas a separação entre a cabeça de Ulisses amarrado ao mastro, os braços dos marinheiros de ouvidos tapados e a voz das sereias.

A ideia de uma política da arte é portanto bastante distinta da ideia de um trabalho que visa tornar as frases de um escritor, as cores de um pintor ou os acordes de um músico adequados à difusão de mensagens ou a produção de representações apropriadas a servir uma causa política. A arte faz política antes que os artistas o façam. Mas sobretudo a arte faz política de um modo que parece contradizer a própria vontade dos artistas de fazer - ou de não fazer - política em sua arte. Quando Flaubert publica Madame Bovary a crítica unânime enxerga na obra do romancista reacionário e partidário da arte pela arte o triunfo da democracia. O privilégio absoluto do estilo indiferente ao 
tema e a recusa de todo julgamento, de toda mensagem social, é justamente isso que aparece para os críticos amedrontados como o triunfo da supressão democrática das diferenças. E quanto ao operário da construção do qual falava há pouco, a recomendação de leitura que faz a seus camaradas, não é Os mistérios de Paris ou algum outro livro descrevendo a condição e o sofrimento do povo. São os grandes livros dos heróis românticos, Werther, René ou Obermann. Pois o que falta aos proletários não é a consciência da condição deles, mas a possibilidade de mudar o ser sensível que está ligado a essa condição. E eles podem fazê-lo somente roubando desses heróis de romance o modo de ser que lhes é, por princípio, recusado, o modo de ser passivo, próprio àqueles que não fazem nada, que não têm ocupação nem lugar na sociedade.

O fundo do problema é simples de expressar: a política da arte própria ao regime estético se carateriza pela ruptura mesma da relação causa/efeito. A deusa não quer nada e o herói dos Doze Trabalhos está em repouso. É preciso não fazer arte para fazer arte e não fazer política para fazer política. A polaridade dessas duas políticas estruturais da arte complica singularmente a ideia de arte política como uma arte que faz tomar consciência de uma realidade e produz, assim, a passagem de uma passividade a uma atividade. O que a política da arte produz não é a passagem de uma ignorância a um saber e de uma passividade a uma atividade. O operário da construção tem tanta necessidade de "ignorar" sua condição quanto de conhecê-la. Pois conhecer também quer dizer reconhecer e consentir, enquanto ignorar também quer dizer não mais reconhecer a regra do jogo, não mais aderir à configuração de um mundo. E ele também precisa adquirir uma certa "passividade". Pois, a quem é ativo com suas mãos pede-se, em geral, que seja passivo quanto ao resto, tanto que ele precisa cessar a atividade dos seus braços para adquirir a atitude "passiva" daquele que contempla o mundo. Uma arte crítica deve portanto ser, à sua maneira, uma arte da indiferença, uma arte que construa o ponto de equivalência de um saber e de uma ignorância, de uma atividade e de uma passividade.

$\mathrm{O}$ artista crítico, Brecht no caso, que quer demonstrar que o nazismo é a única expressão dos interesses capitalistas, sabe que a demonstração deve ser dupla. Ela deve acrescentar ao processo que "faz conhecer" o estado das coisas ao espectador, um processo inverso que o coloque a distância de si mesmo, que o torne estrangeiro a fim de que ele próprio se sinta estrangeiro a este estado de coisas. É preciso que os assuntos de couve-flor de Arturo Ui sejam mais do que assuntos de couve-flor, que eles sejam a alegoria transparente da realidade econômica que sustenta o poder nazista. Mas também é preciso, ao inverso, que sejam apenas assuntos de couve-flor, uma realidade estúpida, insensata, que deve suscitar aquele sentimento de absurdo que nutre ao mesmo tempo o puro prazer lúdico e o sentimento do intolerável. E é preciso que o prosaismo que reduz os grandes discursos sobre o destino do povo a histórias de couve-flor se expresse na solenidade de versos trágicos. 
Assim se estabeleceu a figura estandardizada da arte crítica: a do encontro de elementos heterogêneos, incompatíveis, que instaura um conflito entre dois regimes sensíveis. É preciso entender bem o que esse jogo de heterogêneos quer dizer. Pode-se facilmente reduzi-lo à relação entre uma realidade e uma aparência: uma forma de arte política emblematizou isso: a fotomontagem, que mostra, com John Heartfield, a realidade do ouro capitalista na garganta de Adolf Hitler, ou quarenta anos mais tarde, com Martha Rosler, a realidade das imagens da guerra do Vietnã por trás das imagens publicitárias da felicidade americana. Mas aí onde a aparência se dissolve na realidade, a arte e a política se dissolvem igualmente. Pois ambas estão ligadas à consistência de uma aparência, ao poder que tem uma aparência de reconfigurar o “dado" da realidade, de reconfigurar a própria relação entre aparência e realidade. Neste sentido, arte e política têm em comum o fato de produzirem ficções. Uma ficção não consiste em contar histórias imaginárias. É a construção de uma nova relação entre a aparência e a realidade, o visível e o seu significado, o singular e o comum. Se os assuntos de couve-flor versificados têm a ver com a política, não é porque eles revelariam um segredo ignorado, mas porque eles fazem, à sua maneira, o que faz a política, porque eles embaralham a repartição estabelecida entre a poesia e a prosa, entre a língua dos assuntos públicos e a dos assuntos domésticos, entre os lugares, as funções e as competências. Pois é isso que a política também faz quando manifestantes que representam apenas a si mesmos desafiam o "Estado popular" desfilando sob o cartaz "nós somos o povo” ou quando operários que supostamente deveriam pertencer ao espaço privado do trabalho se declaram como participantes do espaço e da reflexão comuns. Sabe-se, aliás, que muitos desses trabalhadores, como nosso operário da construção, começaram escrevendo em versos, isto é, quebrando a barreira que fazia da prosa a linguagem adequada à condição deles.

A fórmula da arte crítica é marcada por essa tensão. A arte não produz conhecimentos ou representações para a política. Ela produz ficções ou dissensos, agenciamentos de relações de regimes heterogêneos do sensível. Ela os produz não para a ação política, mas no seio de sua própria política, isto é, antes de mais nada no seio desse duplo movimento que, por um lado, a conduz para sua própria supressão e, de outro, aprisiona a política da arte na sua solidão. Ela os produz ocupando essas formas de recorte do espaço sensível comum e de redistribuição das relações entre o ativo e o passivo, o singular e o comum, a aparência e a realidade, que são os espaços-tempos do teatro ou da projeção, do museu ou da página lida. Ela produz, assim, formas de reconfiguração da experiência que são o terreno sobre o qual podem se elaborar formas de subjetivação políticas que, por sua vez, reconfiguram a experiência comum e suscitam novos dissensos artísticos. 
A partir daí, é possível colocar o problema das políticas da arte hoje saindo dos esquemas simplistas como o que opõe o moderno ao pós-moderno. O discurso pós-moderno pressupõe um cenário simples da modernidade, identificada ao paradigma da obra autônoma, da grande arte separada da cultura ou da arte populares. Este paradigma teria voado pelos ares nos anos $60 \mathrm{com}$ a invasão da cultura comunicacional, publicitária e comercial que teria embaralhado a fronteira entre grande arte e arte popular, obra única e reprodução, arte e vida cotidiana. Mas a indefinição das fronteiras é tão antiga quanto o próprio "modernismo". A estátua grega mutilada em torno da qual se organiza o espaço do museu e da estética é ao mesmo tempo arte e não-arte: uma manifestação indiferenciada da vida. E o momento em que a Arte começou a ser nomeada com um A maiúsculo, no início do século XIX, foi também o momento em que começaram a se desenvolver a reprodução, a arte industrial e a indústria literária, o momento em que as obras de arte começaram a se banalizar em objetos comerciais e em decoração do mundo profano, o momento também em que os objetos do mundo ordinário começaram a ultrapassar a fronteira no sentido inverso para produzir novas possibilidades de distância artística a partir da própria proximidade e da mistura das coisas da arte e das coisas do mundo. A mistura é consubstancial ao regime estético da arte. $\mathrm{O}$ que está em questão hoje em dia é a natureza dessa mistura. Não é a perda da arte nos objetos e trabalhos do mundo. É sobretudo a perda do sentido da ficção, a tendência a anular a incisividade do encontro dos heterogêneos, seja para fazer dela a fórmula de um jogo cuja virtude política sempre pressuposta torna-se indecidível, seja um puro testemunho da realidade, seja ainda uma intervenção direta nessa realidade.

Por um lado, a fórmula da arte crítica se banaliza como fórmula da arte lúdica. Há quatro anos atrás uma exposição parisiense colocava lado a lado dispositivos artísticos dos anos 60 e 70 e obras contemporâneas. De modo que as fotomontagens de Martha Rosler, que eu evocava há pouco, estavam expostas à proximidade da obra de um artista contemporâneo chinês, Wang Du, que lançava mão do mesmo princípio de confrontação de dois elementos heterogêneos. Wang Du partira de duas fotos: uma foto oficial do casal Clinton preparando uma viagem à China e uma foto tirada de um site pornográfico chinês que era uma reprodução da Origem do Mundo de Courbet. Ele havia conferido a essas imagens uma realidade plástica: de um lado, o casal Clinton endurecido no sorriso de circunstância como dois manequins de Museu de cera, do outro, esse sexo de mulher escancarado, transformado em estátua de cera. Pode-se ler nesse conjunto tantas formas de derrisão quanto se queira: de um lado a China oficial recebendo o casal americano, de outro a China oficiosa explorando os sites pornôs; de um lado a glória do casal presidencial, do outro a miséria do presidente obrigado a detalhar na televisão o detalhe 
de suas atividades sexuais extraconjugais; de um lado a grandeza da arte e de suas deusas pintadas ou esculpidas, de outro a realidade pornográfica - a realidade da exploração do corpo feminino - ocultada por detrás das sublimações da arte. Poderia acrescentar ainda outros exemplos. Justamente, havia muitos ali. A máquina desmistificadora começa a funcionar sozinha. Ela pode instaurar seu jogo entre um elemento qualquer e qualquer outro elemento, mas, a partir daí, não há mais nada em jogo nesse jogo. O sentido do dispositivo se torna indecidível. Torna-se uma maneira de capitalizar a indecidibilidade de um dispositivo, sua oscilação entre várias significações. Desta forma a mesma exposição pôde ser apresentada nos Estados Unidos com o título pop Let's entertain e em francês com o título Au-delà du spectacle (Para além do espetáculo). Em ambos casos, o que o espectador tinha à sua frente eram dispositivos de instalação “imitando” os brinquedos dos parques de diversão, os mangás ou as novelas, os sons das discotecas, etc. Mas num caso a etiqueta convidava a participar de uma arte "lúdica", consciente da inexistência de qualquer separação efetiva entre seus dispositivos e os dispositivos comerciais que ela imita. No outro, ela convidava a ver na nova contextualização desses dispositivos, nas formas de apresentação da arte dos museus uma crítica do mundo espetacular da mercadoria. O dispositivo artístico vive, assim, da indecidibilidade de seu mecanismo e de seu efeito.

É por isso que a mistura dos heterogêneos tende com frequência, hoje em dia, a se distanciar dessas ambiguidades, a se aproximar de um inventário de coisas, imagens, sons, etc, que constituem nosso universo. Por exemplo, uma exposição intitulada Voilà foi organizada, na ocasião do ano 2000, no Museu de Arte Moderna da Cidade de Paris. A exposição pretendia reunir testemunhos de um século de história comum: fotografias de Hans Peter Feldmann de cem pessoas, com idade entre um e cem anos; instalação por Christian Boltanski de catálogos de telefone de todos os países do mundo, tidos como, eu cito: "espécimes de humanidade"; fotografias de tipos sociais por August Sander. No meio da exposição encontravam-se esses altos-fornos dos Becher de que falava no início e que tendem a se tornar manifestos mudos pelos quais uma exposição de arte contemporânea declara ao mesmo tempo sua seriedade artística e seu engajamento político.

A mais-valia artística e política concedida a esse tipo de trabalhos diz respeito à equivalência que eles estabelecem entre duas políticas. Por um lado, a política do inventário parece opor a seriedade limitada da arte documentária, que simplesmente testemunha sobre o mundo, ao jogo duplo da arte crítica/ lúdica. Mas, por outro, esta arte pratica uma outra forma de jogo duplo. Por um lado a fotografia objetiva nos informa sobre o mundo, no lugar de pretender julgá-lo ou modificá-lo. Mas o mundo sobre o qual ela nos informa é precisamente o mundo abolido. A fotografia do alto-forno abandonado é 
também uma "escultura". Assim como o Torso do Belvedere conservava em suas formas indiferentes a força perdida da liberdade grega, ela conserva tanto o sonho perdido da emancipação operária quanto aquele momento da arte em que os artistas podiam pintar telas abstratas ou construir fábricas. Essas duas políticas da arte são como que conduzidas a sua origem comum. O universo operário e político ao qual essas fotografias nos remetem parecem sobreviver a si mesmos numa tarefa militante da arte que é a de obedecer a certo número de imperativos formais: a objetividade neutra do quadro, a lei das séries. A objetividade fotográfica, a utilização neutra do meio (medium) aparece então como uma dupla fidelidade: fidelidade à ideia de uma obra que não busca fazer arte, a mostrar a arte do seu autor, mas que, ao contrário, sai do mundo da arte pura, para fazer um trabalho de pesquisa reveladora de um mundo social e de suas contradições; mas também a fidelidade ao imperativo que comanda à obra não fazer política, ou melhor, de fazê-la indiretamente: pela sua recusa de toda efusão sentimental e de todo engajamento militante como de todo embelezamento do mundo industrial e comercial; pelo fato mesmo que a imagem não trai nenhuma intenção subjetiva e não vai na direção de nenhuma outra subjetividade; que ela permanece estritamente insignificante e não afetada, aprisionada na sua moldura, como a superfície do quadro na teorização modernista da pintura. À ambivalência do jogo, a forma do inventário contrapõe uma espécie de bivalência. A fotografia do alto-forno é ao mesmo tempo a última forma de autossuficiência da obra autônoma e a última encarnação do torso mutilado que ligava essa autossuficiência a uma promessa de reconciliação entre arte e trabalho. Ela é o emblema congelado de todas as contradições que se entrelaçaram no conceito equívoco de modernidade.

As ambiguidades do jogo e do inventário favorizam o projeto de uma arte que não mais jogaria com o dentro e o fora, a presença e a ausência, que não mais apresentaria duplos dos objetos ou das mensagens do mundo, mas que produziria diretamente coisas do mundo ou intervenções no mundo, uma arte que sairia inteiramente dos lugares tidos como seus ou que faria, ao inverso, o mundo entrar nesses lugares. Ou seja, justamente do que se trata no projeto "Eu e nós". É também o que atestam as múltiplas tentativas contemporâneas para fazer entrar no museu a realidade exterior. Desta forma, nesses últimos anos, vimos as salas de exposição se povoarem de construções ou máquinas diversas - reproduções de moradias, propostas de novas habitações, demonstrações de refinarias ecológicas móveis - e vimos suas paredes se cobrirem de reportagens de ações feitas no exterior, desde as provocações de Santiago Sierra, pagando os operários imigrantes para que eles cavassem suas próprias covas, até as mistificações dos Yes Men brincando de executivos num congresso de empresários. Nesse contexto, a Bienal de São Paulo apresentava a obra de Rene Francisco da qual falava no início entre uma tenda mongol, 
um barco do Ceará, uma reportagem fotográfica sobre a miséria da Polônia pós-socialista e uma reportagem sobre a América capitalista interiorana. O que tornava esse vídeo singular e também lhe conferia seu lado patético era que ele nos lembrava, a partir de um dos últimos países a se reclamarem do comunismo, o que tinha sido o sonho da arte revolucionária: não mais fazer arte, mas construir positivamente os espaços e os edifícios da nova vida. Mas ele o lembrava evidentemente sob a forma de um paliativo derrisório: no lugar de construir as casas funcionais do novo mundo comunista, reformar a casa de um dos esquecidos pela grande promessa estético-política.

Não se trata de fazer chacota desse tipo de engajamento artístico mas de colocar, através dele, um problema. Existe hoje toda uma corrente que propõe uma arte diretamente política na medida em que ela não mais constrói obras feitas para serem contempladas ou mercadorias a serem consumidas, mas modificações do meio ambiente, ou ainda situações apropriadas ao engajamento de novas formas de relações sociais. Existe, por outro lado, um contexto contemporâneo, isto é, aquele a que se chama de consenso. O consenso é bem mais do que aquilo a que o assimilamos habitualmente, a saber, um acordo global dos partidos de governo e de oposição sobre os grandes interesses comuns ou um estilo de governo que privilegia a discussão e a negociação. É um modo de simbolização da comunidade que visa excluir aquilo que é o próprio cerne da política: o dissenso, o qual não é simplesmente o conflito de interesses ou de valores entre grupos, mas, mais profundamente, a possibilidade de opor um mundo comum a um outro. $\mathrm{O}$ consenso tende a transformar todo conflito político em problema que compete a um saber de especialista ou a uma técnica de governo. Ele tende a exaurir a invenção política das situações dissensuais. E esse déficit da política tende a dar um valor de substitutivo aos dispositivos pelos quais a arte entende criar situações e relações novas. Mas essa substituição corre o risco de operar-se dentro das categorias do consenso, levando as veleidades políticas de uma arte saída de si na direção das tarefas políticas de proximidade e de medicina social onde se trata, nos termos do teórico da estética relacional, de "consertar as falhas do vínculo social". Tudo se passa, portanto, como se a tentativa para ultrapassar a tensão inerente à política da arte conduzisse ao seu contrário, isto é, à redução da política ao serviço social e à indistinção ética. Tudo se passa como se fosse preciso de algum modo que a arte, para permanecer política, consentisse em ficar no interior da contradição da sua política.

É o que eu gostaria de ilustrar a través de duas obras recentes que nos falam diversamente de espaço e de habitação, de desvinculação social e de utopia. 
Penso em primeiro lugar no vídeo de Anri Sala Dammi i Colori. Essa obra coloca em cena uma nova encarnação da utopia da arte transformada em formas da vida coletiva. Trata-se do empreendimento do prefeito de Tirana, ele próprio pintor, que decidiu transformar sua cidade pintando todas as fachadas dos prédios em cores vivas. O vídeo nos faz ouvir o discurso do prefeito artista sobre o poder da cor de antecipar uma comunidade e fazer da cidade mais pobre da Europa a única onde todo mundo fala de arte nas ruas e nos cafés. Mas ele o confronta também à realidade muda das cores. Ora a câmera confronta visualmente as cores azul, verde, rosa ou laranja dos prédios às calçadas esburacadas ou cobertas de lixo. Ora ela as trata como um cenário feérico. Ora ela se aproxima e transforma os quadrados de cor em abstrações, indiferentes a todo projeto de transformação da vida. A superfície da obra organiza, assim, a tensão entre a cor que o discurso projeta nas fachadas e a que as fachadas rebatem.

Evocarei também o trabalho de Pedro Costa, consagrado a um grupo de marginais vivendo em meio aos imigrantes cabo-verdianos num subúrbio miserável de Lisboa, pouco a pouco entregue à demolição. Penso sobretudo no segundo filme dessa série: No Quarto de Vanda. O filme é estruturado pela tensão entre os quartos fechados nos quais, seja Vanda e sua irmã, seja um grupo vizinho de ocupantes consomem drogas ao mesmo tempo em que discutem sobre a sua condição, e a rua, onde, enquanto trabalham as escavadeiras, eles se ocupam com negócios mais ou menos lícitos, desde o comércio familiar de legumes da mãe de Vanda até as tentativas dos outros de negociar objetos recuperados ou roubados, que vão da colher ao buquê de flores ou ao passarinho, qual não fosse para ganhar o dinheiro necessário para a droga.

A força do filme está na tensão que ele institui entre esse cenário de vida miserável e as possibilidades estéticas que ele encerra. A cor esverdeada que faz o quarto de Vanda se parecer com um aquário, as pequenas velas que transformam o apartamento sem eletricidade dos drogados em teatro de um claro-obscuro de pintura holandesa, as cores e as arquiteturas singulares reveladas pela própria destruição, tudo isso compõe uma espécie de pictorialidade. Mas essa pictorialidade é ao mesmo tempo incessantemente refutada pelo progresso das escavadeiras.

Uma mesma tensão habita os corpos e as vozes. Por um lado, a tosse, o sofrimento, as vozes do exterior e o barulho da demolição absorvem as falas dos personagens numa espécie de afasia e seus corpos na grande igualdade estética do nada. Mas, por outro lado, essas vozes abafadas e essas pequenas ações aparecem como uma conquista constante sobre o silêncio e a apatia, uma tentativa para tornar seus corpos capazes de continuar e suas falas capazes de refletir a condição deles, de se colocar à altura do destino deles: uma espécie de vitória sobre as máquinas que pouco a pouco os põe para fora de casa. 
Pode-se dizer que esse olhar indiferente, aqui simbolizado pelo olho semicerrado de um gato, se recusa a nos esclarecer a respeito das forças objetivas que produzem tanto a favela quanto sua supressão. Mas também pode-se dizer, inversamente, que essa ausência de explicações nos coloca na presença do que é realmente político: não o conhecimento das razões que produzem tal ou tal vida, mas o confronto direto entre uma vida e o que ela pode. $\mathrm{O}$ filme não se furta a essas tensões. Pelo contrário, ele as coloca em cena. Contudo, ele tampouco se esquiva ao fato de que um filme é apenas um filme, que sua maneira de fazer política está sempre tensionada entre contrários e que sua eficácia depende, em última instância, de algo que tem lugar fora dele.

Tomando esses exemplos, eu não pretendi dizer o que deve ser uma arte política. Tentei, ao inverso, explicar por que não se pode fixar tais normas. O problema não é, como se diz com frequência, que a liberdade da arte seja incompatível com a disciplina política. Ele está no fato da arte ter sua política própria, que não só faz concorrência à outra, mas que também se antecipa às vontades dos artistas. Tentei mostrar que essa política, tensionada entre dois pólos opostos, comporta sempre uma parte de indecidível. Alguns jogam com esse indecidível para fazer dele a auto-demonstração da virtuosidade artística. Outros, como os que eu acabei de evocar, tentam expor as tensões dele. Mas a tentativa de forçar esse indecidível para definir uma boa política da arte conduz, em todos os casos, à supressão conjunta da política e da arte nessa indistinção que leva hoje o nome de ética. 